Check for updates

The BMJ

Cite this as: $B M J 2021 ; 372: \mathrm{n} 547$ http://dx.doi.org/10.1136/bmj.n547 Published: 24 February 2021

\title{
Covid-19: All adults on learning disability register should be prioritised for vaccination, says advisory committee
}

\section{Elisabeth Mahase}

The UK government's vaccine advisory committee has said that all people on the GP Learning Disability Register should now be invited for a covid-19 vaccine as part of priority group 6 .

The Joint Committee on Vaccination and Immunisation (JCVI) said that adults with other related conditions such as cerebral palsy should also be invited and that local authorities should help to identify adults with learning disabilities in residential and nursing care, as well as those who require assisted living support and those in shared accommodation with multiple occupancy.

This will mean that at least 150 ooo more people with learning disabilities should be offered the vaccine more quickly.

The announcement comes after some local GP groups decided to prioritise all patients with learning disabilities for covid-19 vaccination, in response to evidence that disabled patients were at much higher risk from the disease. ${ }^{1}$

Recent figures from the Office for National Statistics showed that $60 \%$ of people in England who died from covid-19 from January to November 2020 had a disability. ${ }^{2}$

The JCVI had previously recommended that adults with severe and profound learning disabilities, and those with learning disabilities in long stay nursing and residential care settings, should be offered the vaccine in priority group 6 . However, there were concerns that people would be missed, as GP systems do not always capture the severity of someone's disability. As such, the committee has now decided that the GP Learning Disability Register should be used, as this is more likely to capture the right people.

\section{Simpler and faster}

Helen Whately, minister for care, said, "I have heard first hand how tough this pandemic has been for people with learning disabilities and their families. We are determined those more at risk from covid should be vaccinated as soon as possible.

"Following the JCVI's updated advice and to make this process simpler and faster, we will be inviting everyone for vaccination who is on their GP's learning disability register. This will mean those who are at a higher risk from the virus can get the protection they need."

Jackie O’Sullivan, executive director of communication, advocacy and activism at the learning disability charity Mencap, called the announcement "fantastic news for people with a learning disability.”
She added, "It's now crucially important that everyone with a learning disability checks that they are on the register and asks to go on it if they are not. Being on the register has many benefits and entitles people to annual health checks and prioritisation for future vaccinations, as well as allowing them to get the covid vaccine and be confident they are protected."

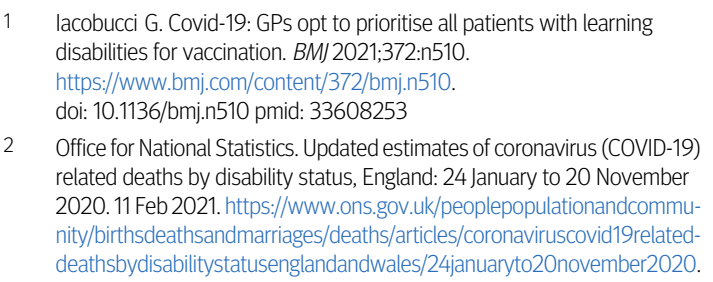

This article is made freely available for use in accordance with BMJ's website terms and conditions for the duration of the covid-19 pandemic or until otherwise determined by BMJ. You may use, download and print the article for any lawful, non-commercial purpose (including text and data mining) provided that all copyright notices and trade marks are retained. 